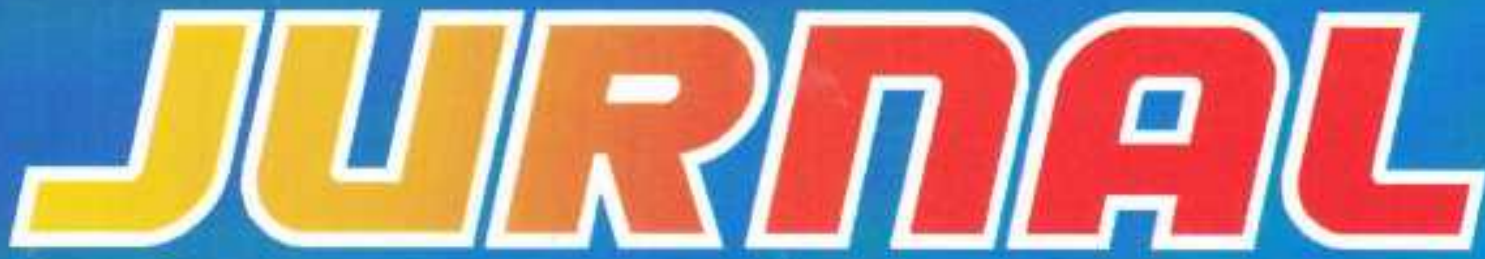

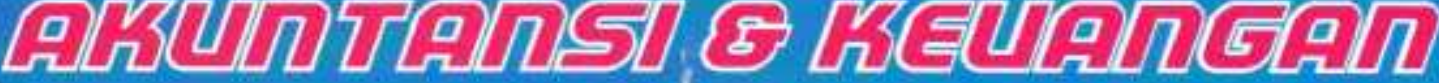

Volume 6, No. 1, Maret 2015

ISSN: $2087-2054$

Pengaruh Peran Acoount Representative Terhadap Tingkat Kepatuhan Wajib Pajak (Studi kasus pada KPP Pratama di Kota Bandar Lampung)

\section{Angrita Denziana \& Handi Sutanto}

Pengaruh Biaya Iklan Dan Biaya Penjualan Personal Terhadap Nilai Penjualan Pada PT Telekomunikasi Indonesia, Tbk.

\section{Chairul Anwar \& Rinna}

Relationship Executives Rewards With Financial Performance On Corporate Banking In Indonesia

\section{Haninun \& Putri Cagora Nisa}

Analisis Penerapan Metode Pengakuan Pendapatan Terhadap Laba Perusahaan Pada Pt. Coca Cola Distribusi Indonesia (Cabang Tanjung Karang)

\section{Herry Goenawan Soedarsa \& Surya Pandelima}

Pengaruh Tingkat Suku Bunga Simpanan Terhadap Jumlah Deposito Pada Pt. Bank Rakyat Indonesia (Persero) Tbk. Cabang Liwa

\section{Indrayenti \& Susanti}

Pengaruh Motivasi Terhadap Minat Mahasiswa Akuntansi Untuk Mengikuti Pendidikan Profesi Akuntansi (PPAK) Di Provinsi Lampung

\section{Rosmiaty Tarmizi \& Julia Restuti}

Pengaruh Kinerja Hutang Terhadap Nilai Perusahaan Pada Perusahaan Pertambangan Batubara Yang Terdaftar Di Bei Periode 2010-2013

\section{Khairudin \& Rico Tanto}

Pengaruh Profitabilitas, Ukuran Perusahaan, Debt To Equity Terhadap Ketepatan Waktu Penyampaian Laporan Keuangan (Studi Pada Perusahaan Asuransi Yang Terdaftar Di BEI)

\section{Riswan \& Tri Lestari Saputri}

Pengaruh Manajemen Laba Terhadap Kinerja Keuangan Pada Perusahaam Manufaktur Tahun 2011-2012

\section{Aminah \& Lidya Natasia Gunakan}




\section{Dewan Pembina}

Dr. Ir. M. Yusuf S. Barusman, M.B.A

Dr. Andala Rama Putra Barusman, S.E., M.A.Ec.

\section{Penanggung Jawab}

Dra. Rosmiaty Tarmizi, M.M.Akt. C.A

\section{Pimpinan Redaksi}

Dr. Angrita Denziana, S.E., M.M, Ak. C.A

\section{Sekretaris Redaksi}

Aminah, S.E., M.S.Ak

Khairudin, S.E., M.S.Ak

\section{Penyuting Ahli}

Prof. Dr. Jogiyanto Hartono, M.B.A. ( Universitas Gadjah Mada)

Tina Miniawati, S.E., M.B.A. (Universitas Trisakti)

Dr. Khomsiyah, S.E., M.M. (Universitas Trisakti)

Dr. Lindrianasari, S.E., M.Si.Akt. (Universitas Lampung)

Sujoko Efferin, Mcom (Hons), MA(Econ), Ph.D. (Universitas Surabaya)

\section{Penerbit}

Universitas Bandar Lampung

Fakultas Ekonomi dan Bisnis Program Studi Akuntansi

SENARAI-Jurnal Akuntansi \& Keuangan Terbit 2 kali setahun pada bulan Maret \&

September

Artikel yang dimuat berupa hasil riset Empiris dan telaah teoritis konsepsual yang kritis dalam kajian bidang akuntansi, auditing, perpajakan, dan keuangan.

\section{Alamat Redaksi}

Gedung G- Program Studi Akuntansi Fakultas Ekonomi dan Bisnis Universitas Bandar Lampung

Kampus A Jalan Z.A Pagar Alam No. 26 Labuan Ratu Bandar Lampung 35142

Telp: (0721) 701979, Fax: (0721) 701467, Email: Prodi.akuntansi@ubl.ac.id 


\section{JURNAL \\ AKUNTANSI \& KEUANGAN}

Volume 6, No. 1, Maret 2015

ISSN: 2087-2054

Pengaruh Peran Acoount Representative Terhadap Tingkat Kepatuhan Wajib Pajak

(Studi Kasus pada KPP Pratama di Kota Bandar Lampung)

Angrita Denziana \& Handi Sutanto

Pengaruh Biaya Iklan dan Biaya Penjualan Personal Terhadap Nilai Penjualan Pada PT

Telekomunikasi Indonesia, Tbk.

\section{Chairul Anwar \& Rinna}

Relationship Executives Rewards With Financial Performance On Corporate Banking In Indonesia

\section{Haninun \& Putri Cagora Nisa}

Analisis Penerapan Metode Pengakuan Pendapatan Terhadap Laba Perusahaan Pada PT. Coca Cola Distribusi Indonesia (Cabang Tanjung Karang)

Herry Goenawan Soedarsa \& Surya Pandelima

Pengaruh Tingkat Suku Bunga Simpanan Terhadap Jumlah Deposito Pada PT. Bank Rakyat Indonesia (Persero) Tbk. Cabang Liwa

Indrayenti \& Susanti

Pengaruh Motivasi Terhadap Minat Mahasiswa Akuntansi Untuk Mengikuti Pendidikan Profesi Akuntansi (PPAK) Di Provinsi Lampung

\section{Rosmiaty Tarmizi \& Julia Restuti}

Pengaruh Kinerja Hutang Terhadap Nilai Perusahaan Pada Perusahaan Pertambangan Batubara Yang Terdaftar Di BEI Periode 2010-2013

\section{Khairudin \& Rico Tanto}

Pengaruh Profitabilitas, Ukuran Perusahaan, Debt To Equity Terhadap Ketepatan Waktu Penyampaian Laporan Keuangan (Studi Pada Perusahaan Asuransi Yang Terdaftar Di BEI) Riswan \& Tri Lestari Saputri

Pengaruh Manajemen Laba Terhadap Kinerja Keuangan Pada Perusahaam Manufaktur Tahun 2011-2012

\section{Aminah \& Lidya Natasia Gunakan}




\section{JURNAL \\ AKUNTANSI \& KEUANGAN}

Volume 6, No. 1, Maret 2015

ISSN: 2087-2054

Daftar Isi

Halaman

$1-22$

Pengaruh Peran Acoount Representative Terhadap Tingkat Kepatuhan

Wajib Pajak (Studi kasus pada KPP Pratama di Kota Bandar Lampung)

Angrita Denziana \& Handi Sutanto

Pengaruh Biaya Iklan Dan Biaya Penjualan Personal Terhadap Nilai

Penjualan Pada PT Telekomunikasi Indonesia, Tbk.

Chairul Anwar \& Rinna

Relationship Executives Rewards With Financial Performance On

Corporate Banking In Indonesia

Haninun \& Putri Cagora Nisa

Analisis Penerapan Metode Pengakuan Pendapatan Terhadap Laba

Perusahaan Pada PT. Coca Cola Distribusi Indonesia (Cabang Tanjung

Karang)

Herry Goenawan Soedarsa \& Surya Pandelima

Pengaruh Tingkat Suku Bunga Simpanan Terhadap Jumlah Deposito Pada

PT. Bank Rakyat Indonesia (Persero) Tbk. Cabang Liwa

Indrayenti \& Susanti

Pengaruh Motivasi Terhadap Minat Mahasiswa Akuntansi Untuk

Mengikuti Pendidikan Profesi Akuntansi (PPAK) Di Provinsi Lampung

Rosmiaty Tarmizi \& Julia Restuti

Pengaruh Kinerja Hutang Terhadap Nilai Perusahaan Pada Perusahaan

Pertambangan Batubara Yang Terdaftar Di BEI Periode 2010-2013

\section{Khairudin \& Rico Tanto}

Pengaruh Profitabilitas, Ukuran Perusahaan, Debt To Equity Terhadap

Ketepatan Waktu Penyampaian Laporan Keuangan (Studi Pada Perusahaan Asuransi Yang Terdaftar Di BEI)

Riswan \& Tri Lestari Saputri

Pengaruh Manajemen Laba Terhadap Kinerja Keuangan Pada Perusahaam Manufaktur Tahun 2011-2012

Aminah \& Lidya Natasia Gunakan 


\section{JURNAL AKUNTANSI \& KEUANGAN}

Volume 6, No. 1, Maret 2015

ISSN: $2087-2054$

\section{Informasi Kebijakan dan Selingkung Berkala}

\section{Kebijakan editorial}

JURNAL Akuntansi \& Keuangan adalah sebuah berkala yang dipublikasikan oleh Universitas Bandar Lampung, yang bertujuan untuk menjadi wadah kreatifitas para akademisi, profesional, peneliti, dan mahasiswa di bidang Akuntansi dan Keuangan termasuk juga bidang Auditing, Sistem Informasi Akuntansi, Tata kelola Perusahaan, Perpajakan, Akuntansi Internasional, Akuntansi Managemen, Akuntansi Keperilakuaan, Pasar Modal dan lain sebagainya. Topik yang semakin meluas di bidang kajian riset Akuntansi diakomodir publikasinya di dalam berkala ini.

Paper yang akan dipublikasikan di dalam berkala JURNAL Akuntansi \& Keuangan harus ditulis di dalam bahasa Indonesia yang baik dan sesuai dengan EYD. Semua instrumen yang digunakan untuk memperoleh data penelitian harus dimasukkan di dalam lampiran paper penelitian, paling tidak, penulis bersedia memberikan klarifikasi atas instrumen yang digunakan saat ada permintaan dari peneliti lainnya.

\section{Sekretariat Editor Berkala}

Gedung F - Fakultas Ekonomi Universitas Bandar Lampung

Fakultas Ekonomi Program Studi Akuntansi

Kampus A Jalan Z.A. Pagar Alam No. 26 Labuhan Ratu Bandar Lampung 35142

$$
\text { Telp.: (0721) 701979, Fax.: (0721) 701467, Email: }
$$

\section{Petunjuk penulisan}

Artikel yang dikirim ke JURNAL Akuntansi \& Keuangan harus mengikuti petunjuk seperti berikut:

1. Naskah merupakan naskah asli yang belum pernah diterbitkan atau sedang dilakukan penilaian pada berkala lain. Naskah ditulis dalam bahasa Indonesia dengan jarak 1 spasi, sepanjang 20-30 halaman kertas A4 dengan tipe huruf Times New Roman.. Naskah dikirim atau diserahkan ke sekretariat JURNAL Akuntansi \& Keuangan rangkap satu disertai disket berikut dengan biodata penulis dan alamat lengkap (kantor dan rumah) pada lembaran yang terpisah dari halaman pertama artikel.

2. Judul naskah dapat ditulis dengan menggambarkan isi pokok tulisan, dan atau ditulis secara ringkas, jelas, dan menarik. 
3. Nama Penulis disertai catatan kaki tentang profesi dan lembaga tempat penulis bekerja dalam naskah yang telah diterima untuk diterbutkan.

4. Abstrak ketik satu spasi, tidak lebih dari 250 kata dalam bahasa Inggris. Abstrak memuat tujuan penelitian, isu, permasalahan, sampel dan metode penelitian, serta hasil dan simpulan (jika memungkinan).

5. Pendahuluan beriksikan uraian tentang latar belakang masalah, ruang lingkup penelitian, dan telaah pustaka yang terkait dengan permasalahan yang dikaji, serta rumusan hipotesis (jika ada). Uraian pendahuluan maksimum $10 \%$ total halaman.

6. Untuk penelitian kuantitatif,

a. Telaah Literatur dan Pengembangan Hipotesis memuat paling tidak satu buah teori yang menjadi dasar pemikiran penelitian. Hipotesis dikembangkan menggunakan asumsi dasar teori dan hasil penelitian sebelumnya. Telah literatur maksimum $40 \%$ total halaman.

b. Metodologi Penelitian meliputi uraian yang rinci tentang bahan yang digunakan, metoda yang dipilih, teknik, dan cakupan penelitian. Uraian bahan dan metoda maksimum $20 \%$ total halaman.

7. Untuk penelitian kualitatif menyesuaikan dengan metodologi kualitatif.

8. Hasil dan Pembahasan merupakan uraian obyektif dari-hasil penelitian dan pembahasan dilakukan untuk memperkaya makna hasil penelitian. Uraian hasil dan pembahasan minimum $25 \%$ total halaman.

9. Simpulan yang merupakan rumusan dari hasil-hasil penelitian. Harus ada sajian dalam satu kalimat inti yang menjadi simpulan utama. Simpulan maksimum 10\% dari keseluruhan lembar artikel.

10. Referensi (Daftar Pustaka) ditulis berurutan berdasarkan alphabetical, disusun menggunakan suku kata terakhir dari nama penulisnya, atau institusi jika dikeluarkan oleh organisasi.

a. Buku: nama penulis, tahun penerbitan, judul lengkap buku, penyunting (jika ada), nama penerbit, dan kota penerbitan.

b. Artikel dalam buku: nama penulis, tahun penerbitan, judul artikel/tulisan, judul buku, nama penyunting, kota penerbitan, nama penerbit, dan halaman.

c. Terbitan berkala: nama penulis, tahun penerbitan, judul tulisan, judul terbitan (bila disingkat, sebaiknya menggunakan singkatan yang baku), volume, nomor, dan halaman.

d. Artikel dalam internet: nama penulis, judul, dan situsnya.

e. Tabel diberi nomor dan judul dilengkapi dengan sumber data yang ditulis dibawah badan tabel, diikuti tempat dan waktu pengambilan data.

f. Ilustrasi dapat berupa gambar, grafik, diagram, peta, dan foto diberi nomor dan judul.

11. Setiap referensi yang digunakan di dalam naskah artikel menggunakan petunjuk yang dirujuk pada The Indonesian Journal of Accounting Research, sebagai berikut:

A. Kutipan dalam tubuh naskah paper harus disesuaikan dengan contoh berikut:

I. Satu sumber kutipan dengan satu penulis (Brownell, 1981).

II. Satu sumber kutipan dengan dua penulis (Frucot dan Shearon, 1991).

III. Satu sumber kutipan dengan lebih dari satu penulis (Hotstede et al., 1990).

IV. Dua sumber kutipan dengan penulis yang berbeda (Dunk, 1990; Mia, 1988).

V. Dua sumber kutipan dengan satu penulis (Brownell, 1981, 1983).

VI. Dua sumber kutipan dengan satu penulis diterbitkan pada tahun yang sama (Brownell, 1982a, 1982b). 
VII. Sumber kutipan dari lembaga harus dinyatakan dengan menggunakan akronim institusi (FASB, 1994)

B. Setiap artikel harus menulis referensi menggunakan panduan berikut:

I. Referensi harus tercantum dalam urutan abjad dari nama belakang penulis atau nama lembaga.

II. Referensi harus dinyatakan dengan urutan sebagai berikut: penulis (s) nama, tahun publikasi, judul kertas atau buku teks, nama jurnal atau penerbit dan nomor halaman. Contoh:

a) Amerika Akuntansi Association, Komite Konsep dan Standar Laporan Keuangan Eksternal. 1977. Pernyataan tentang Teori Akuntansi dan Teori Penerimaan. Sarasota, FL: AAA.

b) Demski, J. S., dan D. E. M. Sappington. 1989. Struktur hirarkis dan akuntansi pertanggungjawaban, Jurnal Akuntansi Penelitian 27 (Spring): 40-58.

c) Dye, R. B., dan R. Magee. 1989. Biaya Kontijensi untuk perusahaan audit. Kertas kerja, Northwestern University, Evansto, IL.

d) Indriantoro, N. 1993. Pengaruh Penganggaran Partisipatif Terhadap Prestasi Kerja dan Kepuasan Kerja dengan Locus of Control dan Dimensi Budaya sebagai Moderating Variabel. Ph.D. Disertasi. University of Kentucky, Lexington.

e) Naim, A. 1997. Analisis Penggunaan Akuntansi Biaya Produk Dalam Keputusan Harga oligopolistik. Jurnal Ekonomi Dan Bisnis Indonesia 12 (3): 43-50.

f) Porcano, T. M. 1984a. Keadilan distributif dan Kebijakan Pajak. Akuntansi Ulasan 59 (4): 619-636.

g) -------. 1984b. Pengaruh Persepsi Kebijakan Pajak Niat Investasi Perusahaan. The Journal of American Association Perpajakan 6 (Fall): 719.

h) Pyndyk, R. S. dan D. L. Rubinfield. 1987. Model ekonometrik \& Forecasts Ekonomi, 3rd ed. NY: McGraw-Hill Publishing, Inc.

12. Author(s) harus melampirkan CV, alamat email, alamat korespondensi dan pernyataan yang menyatakan pasal tersebut tidak sedang disampaikan kepada atau diterbitkan oleh jurnal lain dalam email tersebut dan /atau pos. 


\title{
PENGARUH BIAYA IKLAN DAN BIAYA PENJUALAN PERSONAL TERHADAP NILAI PENJUALAN PADA PT TELEKOMUNIKASI INDONESIA, TBK.
}

\author{
Chairul Anwar \\ Rinna
}

(Universitas Bandar Lampung)

email: chairul.anwar@ubl.ac.id

email: rinnaester@gmail.com

\begin{abstract}
This research aims to examine the influence of advertising costs and personal selling costs on sales values PT. Telekomunikasi Indonesia, Tbk., period 2006-2012. The first hypothesis in this research is advertising costs influential on sales values PT. Telekomunikasi Indonesia, Tbk. The second hypothesis in this research is personal selling costs influential on sales values PT. Telekomunikasi Indonesia, Tbk. The third hypothesis in this research is advertising costs and personal selling costs influential simultaneous on sales values PT. Telekomunikasi Indonesia, Tbk. Advertising costs gives the bulk approach to public, while personal selling costs gives personal approach by face to face with consumen. The data used in this research is the quantity data as the secondary is financial report PT. Telekomunikasi Indonesia, Tbk., there is in the Indonesia Stock Exchange period 7 years (2006-2012). The technique of data analysis in this research is multiple linier regression and the hypothesis test with t test using SPSS 18.0 for windows. The results research showed that (1) Advertising costs influential on sales values PT. Telekomunikasi Indonesia, Tbk. (2) Personal Selling costs influential on sales values PT. Telekomunikasi Indonesia, Tbk. (3) Advertising costs and personal selling costs influential simultaneous on sales values PT. Telekomunikasi Indonesia, Tbk. Variable advertising costs and personal selling costs give big contribution for the increase sales values PT. Telekomunikasi Indonesia, Tbk.

Keywords : advertising costs, personal selling costs, sales values.
\end{abstract}

\section{Pendahuluan}

Tingkat perekonomian dunia yang sedang menuju ke arah kompetisi global berimplikasi pada peningkatan yang terjadi di Indonesia, termasuk dalam bidang usaha telekomunikasi. PT Telekomunikasi Indonesia (Telkom) adalah salah satu perusahaan telekomunikasi terbesar di Indonesia. Pasar potensial yang telah dimiliki oleh Telkom ini seharusnya dimanfaatkan dengan baik dan didukung dengan strategi promosi dan pembiayaan penjualan yang tepat dalam rangka pemasaran produk. Strategi promosi dalam pemasaran produk PT Telekomunikasi Indonesia, Tbk., didukung dengan pembiayaan iklan dan edukasi pelanggan (personal selling). Pendekatan kepada masyarakat secara massal dilakukan melalui periklanan, sedangkan untuk memberikan pelayanan langsung kepada pelanggan PT Telkom melakukannya melalui biaya edukasi pelanggan (personal selling). 
Selama 3 tahun terakhir nilai penjualan PT Telekomunikasi Indonesia, Tbk., terus meningkat, akan tetapi terjadi fluktuasi pada biaya iklan dan biaya penjualan perseorangan seperti yang terlihat pada tabel di bawah ini:

Tabel 1

Fluktuasi Biaya Iklan, Biaya Penjualan Personal dan Nilai Penjualan PT Telkom tahun 2010-2012

(dalam miliar rupiah)

\begin{tabular}{|c|c|c|c|c|c|c|}
\hline Tahun & $\begin{array}{c}\text { Biaya } \\
\text { Iklan }\end{array}$ & $\begin{array}{c}\% \\
\text { peningkatan }\end{array}$ & $\begin{array}{c}\text { Biaya } \\
\text { Penjualan } \\
\text { Personal }\end{array}$ & $\begin{array}{c}\% \\
\text { peningkatan }\end{array}$ & $\begin{array}{c}\text { Nilai } \\
\text { Penjualan }\end{array}$ & $\begin{array}{c}\% \\
\text { peningkatan }\end{array}$ \\
\hline 2010 & $\operatorname{Rp~} 1.994$ & $15,66 \%$ & $\operatorname{Rp~} 398$ & $-9,13 \%$ & $\operatorname{Rp} 68.629$ & $1,41 \%$ \\
\hline 2011 & $\operatorname{Rp} 2.743$ & $37,56 \%$ & $\operatorname{Rp} 427$ & $7,29 \%$ & $\operatorname{Rp} 71.253$ & $3,82 \%$ \\
\hline 2012 & $\operatorname{Rp} 2.494$ & $-9,08 \%$ & $\operatorname{Rp} 491$ & $14,9 \%$ & $\operatorname{Rp} 77.143$ & $8,27 \%$ \\
\hline
\end{tabular}

Sumber : www.idx.co.id

Data dari tabel menunjukkan pada tahun 2012, PT Telekomunikasi Indonesia Tbk (Telkom) mencatat peningkatan nilai penjualan terbesar selama 3 tahun terakhir sehingga menimbulkan peningkatan laba bersih sekitar 17,2\% atau sekitar Rp. 12,9 triliun. Akan tetapi pada tahun 2012, PT Telekomunikasi Indonesia, Tbk., melakukan optimalisasi biaya salah satunya pada biaya periklanan yang menjadi bagian dari rangkaian strategi pemasaran produk perusahaan dengan menurunkan biaya iklan sekitar 9,1\% dari tahun 2011. Sedangkan untuk biaya penjualan personal pada tahun 2012 terjadi peningkatan sekitar 15\% menjadi Rp. 491 miliar.

Peningkatan yang terus terjadi pada nilai penjualan PT Telekomunikasi Indonesia, Tbk., diiringi dengan fluktuasi yang terjadi pada biaya iklan dan biaya penjualan personal yang naik dan turun secara bergantian. Mengacu pada hal tersebut, maka penulis membahas bagaimana pengaruh antara biaya iklan dan biaya penjualan personal terhadap nilai penjualan PT Telekomunikasi Indonesia, Tbk., sehingga terlihat pengaruh keduanya terhadap nilai penjualan.

\section{Tinjauan Pustaka}

\subsection{Teori yang mendasari}

Akuntansi Biaya

Perkembangan dunia usaha, pertumbuhan ekonomi, dan kemajuan teknologi yang pesat menjadi faktor utama yang mempengaruhi kegiatan perusahaan dan bidang-bidang lain yang berhubungan dengan dunia usaha untuk terus berkembang. Hal ini berbanding lurus 
dengan terjadinya perkembangan berbagai disiplin ilmu, salah satunya adalah akuntansi yang erat kaitannya dengan dunia usaha.

Setiap pengambilan keputusan dalam perusahaan yang bersifat keuangan harus didasari dengan informasi akuntansi yang tepat. Inilah yang menjadi alasan utama pentingnya peranan akuntansi dalam dunia usaha dan menjadikan akuntansi sebagai suatu profesi yang sangat dibutuhkan dalam dunia usaha. Bidang ilmu akuntansi mengalami perkembangan yang pesat seiring tumbuh dan berkembangnya dunia usaha. Akuntansi biaya merupakan bagian penting dari ilmu akuntansi dan telah berkembang menjadi tools of management, yang berfungsi menyediakan informasi biaya bagi kepentingan manajemen agar dapat menjalankan fungsinya dengan baik. Pengertian akuntansi biaya menurut beberapa pakar antaralain:

Menurut Mulyadi

"Akuntansi biaya adalah proses pencatatan, penggolongan, peringkasan dan penyajian b iaya pembuatan dan penjualan produk atau jasa, dengan cara cara tertentu, serta penafsiran terhadapnya. Pendapat Horngren et. al (2005:3) mendefinisikan"Akuntansi Biaya menyediakan informasi yang dibutuhkan untuk akuntansi manajemen dan akuntansi keuangan. Akuntansi biaya mengukur dan melaporkan setiap informasi keuangan dan non keuangan yang terkait dengan biaya perolehan atau pemanfaatan sumber daya suatu organisasi."

Sehingga dapat disimpulkan akuntansi biaya adalah bidang akuntansi yang mempelajari secara khusus mengenai biaya dan pengaruhnya terhadap aktivitas perusahaan. Pentingnya akuntansi biaya bagi perusahaan adalah dalam hal merencanakan alokasi sumber ekonomi yang dikorbankan untuk menghasilkan keluaran sehingga perusahaan dapat memperoleh nilai keluaran yang memiliki nilai ekonomis yang lebih tinggi dibandingkan dengan nilai masukan yang dikorbankan (Mulyadi: 2005).

\section{Klasifikasi Biaya}

Informasi biaya yang tepat dan akurat dapat menjadi dasar yang kuat untuk pengambilan keputusan yang dilakukan manajemen. Dalam mengalokasikan biaya, manajemen melakukan pengklasifikasian biaya didasarkan pada tujuan dari informasi biaya tersebut. Perbedaan tujuan membuat timbulnya perbedaan dalam pengklasifikasian biaya. Seperti konsep akuntansi biaya: "different costs for different purposes" (Mulyadi: 2005).

\section{Analisis Biaya Pemasaran}

Penggolongan biaya pemasaran menurut Mulyadi (2005: 488), adalah sebagai berikut:

1. Penggolongan secara garis besar, yaitu 
a. Biaya untuk mendapatkan pesanan (order-getting costs), yaitu semua biaya yang dikeluarkan untuk memperoleh pesanan.

b. Biaya untuk memenuhi pesanan (order-filling costs), yaitu semua biaya yang dikeluarkan untuk mengusahakan agar produk sampai ke tangan pembeli dan biayabiaya untuk mengumpulkan uang dari pembeli.

2. Penggolongan menurut fungsi pemasaran, yaitu:

a. Fungsi penjualan yang terdiri dari kegiatan untuk memenuhi pesanan yang diterima dari pelanggan.

b. Fungsi advertensi terdiri dari kegiatan perencanaan dan pelaksanaan kegiatan order getting melalui kegiatan advertensi dan promosi.

c. Fungsi pergudangan terdiri dari kegiatan penyimpanan produk siap dijual.

d. Fungsi pembungkusan dan pengiriman terdiri dari kegiatan pembungkusan produk dan pengiriman produk kepada pembeli.

e. Fungsi kredit dan penagihan terdiri dari kegiatan pemantauan kemampuan keuangan pelanggan dan penagihan piutang dari pelanggan.

f. Fungsi akuntansi pemasaran terdiri dari kegiatan pembuatan faktur dan penyelenggaraan catatan akuntansi penjualan.

Biaya pemasaran memiliki karakteristik yang berbeda dengan biaya produksi. Mulyadi (2005: 489) mengungkapkan karakteristik biaya pemasaran adalah sebagai berikut:

1. Biaya pemasaran antara perusahaan yang satu dengan yang lain tidak dapat dibandingkan karena perusahaan yang sejenis produknya pun belum tentu menepuh cara pemasaran yang sama.

2. Metode pemasaran produk bersifat fleksibel, terus berkembang sesuai perubahan kondis pasar. Hal ini menimbulkan masalah dan interprestasi biaya pemasaran.

3. Kegiatan pemasaran yang berhadapan dengan konsumen merupakan variabel yang tidak dapat dikendalikan oleh perusahaan, sedangkan tingkat efisiensi pemasaran diukur melalui kenaikan volume penjualan dan laba.

4. Terdapat biaya tidak langsung dan biaya bersama (joint costs) yang lebih kompleks dalam biaya pemasaran dibandingkan di dalam biaya produksi.

\section{Pengertian Biaya Iklan}

Menurut Kotler dan Amstrong (2010:426) menyatakan bahwa iklan adalah segala bentuk presentasi non-personal dan promosi yang dibayar. Sedangkan menurut Shimp (2007:240) menyatakan bahwa iklan adalah bentuk komunikasi berbayar yang dilakukan 
dengan tujuan memperngaruhi penerima pesan untuk mengambil sebuah tindakan baik sekarang maupun dikemudian hari. Dari beberapa pengertian di atas dapat disimpulkan bahwa biaya iklan adalah biaya yang dikeluarkan perusahaan untuk media yang digunakan dalam memasarkan produknya kepada konsumen melalui pesan verbal maupun visual.

Adapun tujuan periklanan menurut Kotler (2005:278) dapat digolongkan menjadi iklan informatif, iklan persuasif, iklan pengingat, dan iklan penguatan. Kotler (2005:277) mengungkapkan ada lima keputusan utama dalam pembuatan program periklanan yang disebut $5 \mathrm{M}$, yaitu:

1. Tujuan periklanan (Mission)

2. Anggaran yang digunakan (Money)

3. Pesan yang ingin disampaikan (Message)

4. Media yang digunakan (Media)

5. Evaluasi periklanan yang telah dijalankan (Measurement)

\section{Pengertian Biaya Penjualan Personal}

Penjualan personal merupakan bentuk presentasi personal dari bagian penjualan perusahaan dengan tujuan menciptakan penjualan dan membangun hubungan dengan pelanggan. Yang dilakukan dengan interaksi tatap muka terhadap calon pembeli (Kotler, 2005:249). Sedangkan menurut Cron dan Decarlo (2010:3), penjualan personal di definisikan sebagai komunikasi langsung antara representatif yang dibayar dan prospek yang mengarah pada transaksi, kepuasan pelanggan dan hubungan yang menguntungkan.

Sehingga dapat disimpulkan bahwa biaya penjualan personal adalah biaya yang dikeluarkan perusahaan untuk melakukan interaksi tatap muka dengan pelanggan untuk mencapai tujuan perusahaan. Kotler dan Amstrong (2010:496) menjelaskan bahwa penjualan personal memiliki beberapa aspek penting, antaralain prospecting, approach, presentation, handling objection closing, dan follow up

\section{Pengertian Nilai Penjualan}

Menurut Swastha (2004:403) yaitu, "Penjualan adalah interaksi antara individu saling bertemu muka yang ditujukan untuk menciptakan, memperbaiki, menguasai atau mempertahankan hubungan pertukaran sehingga menguntungkan bagi pihak lain". Menurut Winarto dan Ismaya (2003:380), "Penjualan adalah transaksi yang melibatkan pengiriman atau penyerahan produk; hak atau jasa dalam pertukaran untuk penerimaan kas, janji pembayaran, atau yang dapat disamakan dengan uang atau kombinasinya”. 
Penjualan dapat diartikan juga sebagai usaha yang dilakukan oleh dua pihak untuk mencapai tujuan mendapatkan barang dan imbalan sebagai kontraprestasinya. Berdasarkan pengertian tersebut dapat dinyatakan bahwa nilai penjualan adalah total dari hasil penjualan yang dicapai oleh perusahaan dari suatu kegiatan usaha dalam periode tertentu. Dengan demikian kegunaan nilai penjualan adalah sebagai pernyataan dalam perhitungan keuntungan.

\subsection{Penelitian Terdahulu dan Hipotesis}

Penelitian terdahulu yang diacu dalam penelitian ini adalah penelitian yang telah dilakukan oleh Fortuinisa dan Agassi (2013) dalam jurnal yang berjudul, "Pesan Iklan Televisi dan Personal Selling: Alat Promosi Untuk Peningkatan Keputusan Pembelian”. Penelitian ini menggunakan biaya iklan dan biaya penjualan personal sebagai variabel independen, dan keputusan pembelian sebagai variabel dependen. Berdasarkan metode analisis regresi linier berganda dalam penelitian ini, diperoleh hasil penelitian bahwa pesan dan iklan berpengaruh positif dan signifikan terhadap keputusan pembelian.

Sedangkan jurnal Dani (2007) dengan judul, "Hubungan Periklanan, Publisitas, dan Promosi Penjualan dengan Penjualan" menggunakan variabel biaya periklanan, biaya publisitas, biaya promosi penjualan sebagai variabel independen dan penjualan sebagai variabel dependen. Penelitian ini menggunakan analisis linier berganda dan uji signifikansi alpha $0,05(5 \%)$ dan didapatkan hasil dari penelitian ini adalah ketiga variabel independen, yaitu biaya periklanan, biaya publisitas dan biaya promosi penjualan berhubungan sangat kuat dan signifikan terhadap penjualan sebagai variabel dependen. Berdasarkan latar belakang dan masalah pokok yang dikemukakan, maka hipotesis dapat dirumuskan sebagai berikut:

$\mathrm{H}_{1}$ : Biaya iklan berpengaruh terhadap nilai penjualan pada PT Telekomunikasi Indonesia, Tbk.

$\mathrm{H}_{2}$ : Biaya penjualan personal berpengaruh terhadap nilai penjualan pada PT Telekomunikasi Indonesia, Tbk.

\section{Metodologi Penelitian}

\subsection{Pemilihan Sampel}

Sampel yang digunakan dalam penelitian ini adalah laporan keuangan PT Telekomunikasi Indonesia, Tbk., periode 7 tahun (2006-2012). 


\subsection{Data}

Data yang diperoleh adalah data sekunder yaitu berupa informasi tertulis mengenai informasi biaya iklan, biaya penjualan personal dan nilai penjualan PT Telekomunikasi Indonesia, Tbk selama periode 7 tahun yaitu dari tahun 2006 sampai dengan tahun 2012 yang didapatkan melalui www.idx.co.id. Metode pengumpulan data yang digunakan penulis dalam penelitian ini adalah penelitian pustaka (library research).

\subsection{Model Penelitian dan Pengujian Statistika}

\section{Pengujian Kualitas Data}

Pengujian kualitas data menggunakan uji validitas dan reliabilitas. Validitas adalah suatu ukuran yang menunjukkan tingkat-tingkat kevalidan atau kesahihan sesuatu instrumen (Arikunto, 2005: 144). Sugiyono (2007:1) menyatakan, bahwa reliabilitas adalah hasil penelitian dimana terdapat kesamaan data dalam waktu yang berbeda. Suatu variabel dikatakan reliabel jika menghasilkan nilai Cronbach's Alpha $>0,60$. Dan jika sebaliknya maka dikatakan data tersebut tidak valid. (Ghozali, 2009:45)

\section{Analisis Regresi Berganda}

Regresi berganda digunakan untuk menggambarkan model hubungan antara variabel bebas dan variabel terikatnya. Dengan persamaan regresi berganda sebagai berikut:

$$
\mathbf{Y}=\mathbf{a}+\mathbf{b} 1 \mathbf{X} 1+\mathbf{b} 2 \mathbf{X} 2+\mathbf{e}
$$

dimana :

$$
\begin{aligned}
\mathrm{Y} & =\text { Nilai Penjualan } \\
\mathrm{X}_{1} & =\text { Biaya Iklan } \\
\mathrm{X}_{2} & =\text { Biaya Penjualan Personal } \\
\mathrm{a} & =\text { Konstanta } \\
\mathrm{b}_{1}, \mathrm{~b}_{2}, \mathrm{~b}_{3} & =\text { Koefisien regresi } \\
\mathrm{e} & =\text { variabel penggangu }
\end{aligned}
$$

\section{Uji Hipotesis}

\section{Uji t}

Uji t digunakan menguji tingkat signifikan atau keberartian masing-masing variabel $\mathrm{X}$ terhadap variabel $\mathrm{Y}$. Uji t dilakukan untuk mengetahui pengaruh masing-masing variabel independen yang terdiri dari biaya promosi penjualan dan biaya penjualan personal terhadap nilai penjualan. Suatu variabel akan memiliki pengaruh yang signifikan bila $t_{\text {hitung variabel }}$ 
tersebut lebih besar dibanding nilai $t_{\text {tabel. }}$ Pengambilan keputusan dilakukan dengan membandingkan nilai $t_{\text {hitung }}$ dengan $t_{\text {tabel }}$ dengan kriteria sebagai berikut:

Jika nilai thitung $<\mathrm{t}$ tabel maka $\mathrm{H}_{\mathrm{o}}$ diterima dan $\mathrm{H}_{\mathrm{a}}$ ditolak.

Jika nilai thitung $>\mathrm{t}$ tabel maka $\mathrm{H}_{\mathrm{o}}$ ditolak dan $\mathrm{H}_{\mathrm{a}}$ diterima.

\section{Uji F}

Uji F, yaitu uji untuk melihat pengaruh variabel bebas secara bersama-sama (simultan) terhadap variabel terikatnya dengan membandingkan $\mathrm{F}_{\text {hitung }}$ dan $\mathrm{F}_{\text {tabel }}$, kriterianya:

Jika $\mathrm{F}_{\text {hitung }}>\mathrm{F}_{\text {tabel}}$, makaH $_{\mathrm{o}}$ ditolak dan $\mathrm{H}_{\mathrm{a}}$ diterima.

Jika $\mathrm{F}_{\text {hitung }}>\mathrm{F}_{\text {tabel}}$, makaH $_{\mathrm{o}}$ diterima dan $\mathrm{H}_{\mathrm{a}}$ ditolak.

\section{Koefisien Determinasi $\left(\mathbf{R}^{\mathbf{2}}\right)$}

Menurut Setiaji (2004:20), koefisien determinasi $\left(\mathrm{R}^{2}\right)$ digunakan untuk mengukur seberapa jauh kemampuan variabel bebas dalam menerangkan variabel terikatyang di hitung dengan cara mengkuadratkan hasil korelasi kemudian dikalikan dengan 100\%.

\subsection{Definisi Operasional Variabel}

Berikut ini akan dijelaskan mengenai variabel dalam penelitian ini:

1. Biaya iklan $\left(\mathrm{X}_{1}\right)$ adalah data dalam bentuk biaya iklan PT Telekomunikasi Indonesia, Tbk., dalam periode 7 tahun, yaitu tahun $2006-2012$.

2. Biaya penjualan personal $\left(\mathrm{X}_{2}\right)$ adalah data dalam bentuk biaya penjualan personal PT Telekomunikasi Indonesia, Tbk., periode 7 tahun, yaitu tahun 2006 - 2012.

3. Nilai penjualan (Y) adalah data dalam bentuk total penjualan PT Telekomunikasi Indonesia, Tbk., dalam periode 7 tahun, yaitu tahun $2006-2012$.

\section{Hasil dan Pembahasan}

\subsection{Data Penelitian}

Persentase peningkatan biaya iklan PT Telekomunikasi Indonesia, Tbk., periode 7 tahun (2006-2012) adalah sebagai berikut: 


\section{Tabel 2}

Persentase Biaya Iklan Tahun 2006-2012

\begin{tabular}{|c|cc|c|}
\hline Tahun & Biaya Iklan & $\begin{array}{c}\text { Persentase } \\
\text { peningkatan }\end{array}$ \\
\hline 2006 & $\operatorname{Rp} 944.000 .000 .000$ & - \\
\hline 2007 & $\operatorname{Rp~} 1.301 .000 .000 .000$ & $37,82 \%$ \\
\hline 2008 & $\operatorname{Rp~} 1.876 .000 .000 .000$ & $44,20 \%$ \\
\hline 2009 & $\operatorname{Rp~} 1.724 .000 .000 .000$ & $-8,10 \%$ \\
\hline 2010 & $\operatorname{Rp~} 1.994 .000 .000 .000$ & $15,66 \%$ \\
\hline 2011 & $\operatorname{Rp~2.743.000.000.000}$ & $37,56 \%$ \\
\hline 2012 & $\operatorname{Rp~2.494.000.000.000~}$ & $-9,08 \%$ \\
\hline
\end{tabular}

Sumber: www.idx.co.id, 2013

Persentase peningkatan biaya penjualan personal PT Telekomunikasi Indonesia, Tbk., periode 7 tahun (2006-2012) adalah sebagai berikut:

Tabel 3

Persentase Biaya Penjualan Personal Tahun 2006-2012

\begin{tabular}{|c|cc|c|}
\hline Tahun & \multicolumn{2}{|c|}{ Biaya Penjualan Personal } & $\begin{array}{c}\text { Persentase } \\
\text { peningkatan }\end{array}$ \\
\hline 2006 & $\mathrm{Rp}$ & 268.000 .000 .000 & - \\
\hline 2007 & $\mathrm{Rp}$ & 425.000 .000 .000 & $58,58 \%$ \\
\hline 2008 & $\mathrm{Rp}$ & 417.000 .000 .000 & $-1,88 \%$ \\
\hline 2009 & $\mathrm{Rp}$ & 438.000 .000 .000 & $5,04 \%$ \\
\hline 2010 & $\mathrm{Rp}$ & 398.000 .000 .000 & $-9,13 \%$ \\
\hline 2011 & $\mathrm{Rp}$ & 427.000 .000 .000 & $7,29 \%$ \\
\hline 2012 & $\mathrm{Rp}$ & 491.000 .000 .000 & $14,99 \%$ \\
\hline
\end{tabular}

Sumber: www.idx.co.id, 2013

Persentase peningkatan nilai penjualan PT Telekomunikasi Indonesia, Tbk., periode 7 tahun (2006-2012) adalah sebagai berikut:

\section{Tabel 4}

Persentase Nilai Penjualan Tahun 2006-2012

\begin{tabular}{|c|cc|c|}
\hline Tahun & \multicolumn{2}{|c|}{ Nilai Penjualan } & $\begin{array}{c}\text { Persentase } \\
\text { Peningkatan }\end{array}$ \\
\hline 2006 & $\mathrm{Rp}$ & 51.294 .000 .000 .000 & - \\
\hline 2007 & $\mathrm{Rp}$ & 59.440 .000 .000 .000 & $15,88 \%$ \\
\hline 2008 & $\mathrm{Rp}$ & 60.690 .000 .000 .000 & $2,10 \%$ \\
\hline 2009 & $\mathrm{Rp}$ & 67.678 .000 .000 .000 & $11,51 \%$ \\
\hline 2010 & $\mathrm{Rp}$ & 68.629 .000 .000 .000 & $1,41 \%$ \\
\hline 2011 & $\mathrm{Rp}$ & 71.253 .000 .000 .000 & $3,82 \%$ \\
\hline 2012 & $\mathrm{Rp}$ & 77.143 .000 .000 .000 & $8,27 \%$ \\
\hline
\end{tabular}

Sumber: www.idx.co.id, 2013 


\subsection{Uji Validitas dan Uji Reliabilitas}

\section{Tabel 5}

Hasil Uji Validitas Variabel $X_{1}, X_{2}$, dan $Y$

\begin{tabular}{|c|c|c|c|c|}
\hline Item & $\mathrm{r}$ hitung & $\mathrm{r}$ tabel & Kondisi & Keterangan \\
\hline $\mathrm{X} 1$ & 0,891 & 0,669 & $\mathrm{r}$ hitung $>\mathrm{r}$ tabel & Valid \\
\hline $\mathrm{X} 2$ & 0,832 & 0,669 & $\mathrm{r}$ hitung $>\mathrm{r}$ tabel & Valid \\
\hline $\mathrm{Y}$ & 0,910 & 0,669 & $\mathrm{r}$ hitung $>\mathrm{r}$ tabel & Valid \\
\hline
\end{tabular}

Sumber: data diolah, 2013

Pengujian validitas dan reliabilitas data dilakukan terhadap biaya iklan, biaya penjualan personal dan nilai penjualan PT Telkom, Tbk., dalam periode 2006-2012. Pengujian data dengan menggunakan program SPSS 18.0, hasil menunjukkan variabel yang diuji dalam penelitian ini valid, terlihat dari nilai $r_{\text {hitung }}$ yang lebih besar dari $r_{\text {tabel }}$.

\section{Tabel 6}

Hasil Uji Reliabilitas Variabel $X_{1}, X_{2}$, dan $Y$

Reliability

Statistics

\begin{tabular}{|r|r|}
\hline $\begin{array}{c}\text { Cronbach's } \\
\text { Alpha }\end{array}$ & $\begin{array}{c}\text { N of } \\
\text { Items }\end{array}$ \\
\hline, 888 & 3 \\
\hline
\end{tabular}

Sumber: data diolah, 2013

Pengujian reliabilitas data dilakukan dengan menggunakan program SPSS 18.0, yaitu dilihat dari nilai Cronbach's Alpha. Nilai Cronbach's Alpha sebesar 0,888 lebih besar dari 0,60 sehingga dinyatakan item reliabel.

\section{Pengujian Hipotesis, Hasil dan Diskusi}

Tabel 7

Hasil Uji Analisis Regresi Berganda

Coefficients $^{\mathrm{a}}$

\begin{tabular}{|c|c|c|c|c|c|c|}
\hline \multicolumn{2}{|c|}{ Model } & \multicolumn{2}{|c|}{$\begin{array}{l}\text { Unstandardized } \\
\text { Coefficients }\end{array}$} & \multirow{2}{*}{$\begin{array}{c}\begin{array}{c}\text { Standardized } \\
\text { Coefficients }\end{array} \\
\text { Beta }\end{array}$} & \multirow[t]{2}{*}{$\mathrm{T}$} & \multirow[t]{2}{*}{ Sig. } \\
\hline & & $\mathrm{B}$ & Std. Error & & & \\
\hline \multirow[t]{3}{*}{1} & (Constant) & 28767,9 & 9419,632 & & 3,054 & 0,038 \\
\hline & $\mathrm{x} 1$ & 8,253 & 3,37 & 0,603 & 2,449 & 0,071 \\
\hline & $x 2$ & 51,269 & 30,882 & 0,409 & 1,66 & 0,172 \\
\hline
\end{tabular}

Sumber: data diolah, 2013

Berdasarkan pengolahan data diperoleh persamaan regresi berganda sebagai berikut :

$$
Y=28767,9+8,253 X_{1}+51,269 X_{2}
$$


Nilai konstanta sebesar 28767,9 menunjukkan jika biaya iklan dan biaya penjualan personal adalah konstan atau sama dengan nol (0), maka nilai penjualan pada PT Telkom, Tbk., sebesar 28767,9 (dalam miliar rupiah) dalam periode 2006-2012. Nilai koefisien regresi variabel biaya iklan sebesar 8,253 menunjukkan setiap penambahan biaya iklan sebesar 1 (dalam miliar rupiah) maka akan meningkatkan nilai penjualan sebesar 8,253 (dalam miliar rupiah). Sedangkan nilai koefisien regresi dari variabel biaya penjualan personal menunjukkan nilai 51,269, hal ini berarti setiap penambahan biaya penjualan personal sebesar 1 (dalam miliar rupiah) maka akan meningkatkan nilai penjualan sebesar 51,269 (dalam miliar rupiah).

\section{Pengaruh Biaya Iklan Terhadap Nilai Penjualan}

Hipotesis yang penulis ajukan dalam penelitian yang dilakukan pada PT Telekomunikasi Indonesia, Tbk., periode 2006-2012 ini adalah sebagai berikut:

Ho: Biaya iklan tidak berpengaruh terhadap nilai penjualan PT Telekomunikasi Indonesia, Tbk.,

Ha: Biaya iklan berpengaruh terhadap nilai penjualan PT Telekomunikasi Indonesia, Tbk.,

Tabel 8

Hasil Uji t Variabel $X_{1}$ dan $Y$

Coefficients $^{\mathrm{a}}$

\begin{tabular}{|c|c|c|c|c|c|}
\hline \multirow[t]{2}{*}{ Model } & \multicolumn{2}{|c|}{$\begin{array}{c}\text { Unstandardized } \\
\text { Coefficients }\end{array}$} & \multirow{2}{*}{$\begin{array}{c}\text { Standardized } \\
\text { Coefficients } \\
\text { Beta }\end{array}$} & \multirow[b]{2}{*}{$\mathrm{T}$} & \multirow[b]{2}{*}{ Sig. } \\
\hline & $\mathrm{B}$ & $\begin{array}{l}\text { Std. } \\
\text { Error }\end{array}$ & & & \\
\hline 1 (Constant) & 42355,864 & 5419,678 & & 7,815 &, 001 \\
\hline $\mathrm{x} 1$ & 12,208 & 2,770 & ,892 & 4,407 & 007 \\
\hline
\end{tabular}

Sumber : data diolah, 2013

Berdasarkan pengolahan data diperoleh nilai $t_{\text {hitung }}$ sebesar 4,407 dengan menggunakan derajat kepercayaan 95\% $(\alpha=0,05)$ diperoleh nilai $t_{\text {tabel }}$ sebesar 2,015. Dengan demikian dikarenakan $\mathrm{t}_{\text {hitung }}>\mathrm{t}_{\text {tabel }}$ yaitu 4,407 $>$ 2,015 dapat disimpulkan bahwa Ho ditolak dan Ha diterima yang menunjukkan biaya iklan $\left(\mathrm{X}_{1}\right)$ berpengaruh terhadap nilai penjualan PT Telekomunikasi Indonesia, Tbk. Hal ini menunjukkan dengan pengalokasian biaya iklan yang tepat maka akan memberikan dampak pada peningkatan nilai penjualan pada PT Telekomunikasi Indonesia, Tbk. 


\section{Pengaruh Biaya Penjualan Personal Terhadap Nilai Penjualan}

Hipotesis yang diajukan dalam penelitian ini adalah:

Ho: Biaya penjualan personal tidak berpengaruh terhadap nilai penjualan PT Telekomunikasi Indonesia, Tbk.,

Ha: Biaya penjualan personal berpengaruh terhadap nilai penjualan PT Telekomunikasi Indonesia, Tbk.,

Tabel 9

Hasil Uji t Variabel $X_{2}$ dan $Y$

Coefficients $^{\mathrm{a}}$

\begin{tabular}{|c|c|c|c|c|c|}
\hline \multirow[t]{2}{*}{ Model } & \multicolumn{2}{|c|}{$\begin{array}{l}\text { Unstandardized } \\
\text { Coefficients }\end{array}$} & $\begin{array}{l}\text { Standardized } \\
\text { Coefficients }\end{array}$ & \multirow[b]{2}{*}{$\mathrm{T}$} & \multirow[b]{2}{*}{ Sig. } \\
\hline & B & Std. Error & Beta & & \\
\hline $1 \quad$ (Constant $)$ & 22305,016 & 12786,954 & & 1,744 &, 142 \\
\hline $\mathrm{x} 2$ & 104,746 & 30,883 & ,835 & 3,392 & ,019 \\
\hline
\end{tabular}

Sumber: data diolah, 2013

Berdasarkan pengolahan data diperoleh nilai $t_{\text {hitung }}$ sebesar 3,392 dengan menggunakan derajat kepercayaan 95\% $(\alpha=0,05)$ diperoleh nilai $t_{\text {tabel }}$ sebesar 2,015. Dengan demikian dikarenakan $t_{\text {hitung }}>t_{\text {tabel }}$ yaitu 3,392 $>$ 2,015 dapat disimpulkan bahwa Ho ditolak dan Ha diterima yang menunjukkan biaya penjualan personal $\left(\mathrm{X}_{2}\right)$ berpengaruh terhadap nilai penjualan PT Telekomunikasi Indonesia, Tbk. Berdasarkan hasil ini dapat disimpulkan bahwa biaya penjualan personal yang disasarkan tepat kepada konsumen dapat berpengaruh terhadap peningkatan nilai penjualan PT Telekomunikasi Indonesia, Tbk.

\section{Pengaruh Biaya Iklan dan Biaya Penjualan Personal Terhadap Nilai Penjualan (Uji F)}

Tabel 10

Hasil Uji F

ANOVAb

\begin{tabular}{|ll|r|r|c|c|c|}
\hline \multicolumn{2}{|l|}{ Model } & Sum of Squares & \multicolumn{1}{c|}{ df } & Mean Square & F & \multicolumn{1}{c|}{ Sig. } \\
\hline 1 & Regression & 390233513,908 & 2 & 195116756,954 & 14,501 &, 015 \\
& Residual & 53822958,092 & 4 & 13455739,523 & & \\
Total & 444056472,000 & 6 & & & \\
\hline
\end{tabular}

Sumber: data diolah, 2013

Berdasarkan pengolahan data diperoleh nilai $F_{\text {hitung }}$ sebesar 14,501, dengan derajat kepercayaan 95\% diperoleh nilai $F_{\text {tabel }}$ sebesar 6,944. Dengan demikian dikarenakan $F_{\text {hitung }}>$ $\mathrm{F}_{\text {tabel }}$ yaitu 14,501 > 6,944, disimpulkan bahwa Ho ditolak dan Ha diterima, menunjukkan 
biaya iklan dan biaya penjualan personal berpengaruh secara simultan terhadap nilai penjualan PT Telekomunikasi Indonesia, Tbk.

\section{Tabel 11}

Hasil Uji Koefisien Determinasi $\left(\mathbf{R}^{2}\right)$ Model Summary ${ }^{\mathrm{b}}$

\begin{tabular}{|c|c|r|r|c|}
\hline Model & $\mathrm{R}$ & $\begin{array}{c}\mathrm{R} \\
\text { Square }\end{array}$ & $\begin{array}{c}\text { Adjusted R } \\
\text { Square }\end{array}$ & $\begin{array}{c}\text { Std. Error of the } \\
\text { Estimate }\end{array}$ \\
\hline 1 &, 937 &, 879 &, 818 & 3668,20658 \\
\hline
\end{tabular}

Sumber: data diolah, 2013

Diperoleh pula nilai koefisien determinasi $\left(\mathrm{R}^{2}\right)$ sebesar 0,879 atau $87,9 \%$ yang berarti besarnya sumbangan atau kontribusi dari biaya iklan dan biaya penjualan personal terhadap nilai penjualan PT Telekomunikasi Indonesia, Tbk., sebesar 87,9\% sedangkan sisanya sebesar $12,1 \%$ dipengaruhi oleh faktor lain yang tidak diteliti.

\section{Simpulan dan Saran}

\subsection{Simpulan}

Pembahasan dan pengujian hipotesis yang telah dilakukan mengenai pengaruh biaya iklan dan biaya penjualan personal terhadap nilai penjualan PT Telekomunikasi Indonesia, Tbk.,memperoleh beberapa kesimpulan, yaitu:

1. Berdasarkan hasil pengujian hipotesis dengan menggunakan uji $t$ diketahui bahwa biaya iklan $\left(\mathrm{X}_{1}\right)$ berpengaruh terhadap nilai penjualan PT Telekomunikasi Indonesia, Tbk., dalam periode penelitian 7 tahun yaitu dari tahun 2006-2012.

2. Berdasarkan hasil pengujian hipotesis dengan menggunakan uji t diketahui bahwa biaya penjualan personal $\left(\mathrm{X}_{2}\right)$ berpengaruh terhadap nilai penjualan PT Telekomunikasi Indonesia, Tbk., dalam periode penelitian 7 tahun yaitu dari tahun 2006-2012.

3. Berdasarkan hasil pengujian hipotesis dengan menggunakan uji $\mathrm{F}$ diketahui bahwa biaya iklan dan biaya penjualan personal berpengaruh secara simultan terhadap nilai penjualan PT Telekomunikasi Indonesia, Tbk., dalam periode penelitian 7 tahun yaitu dari tahun 2006-2012.

4. Keputusan manajemen mengeluarkan biaya untuk iklan dan penjualan personal dapat memberikan pendekatan kepada konsumen secara massal maupun personal. Terlihat dari hasil pengujian yang menunjukkan biaya iklan dan biaya penjualan personal memberikan kontribusi yang besar terhadap peningkatan nilai penjualan PT 
Telekomunikasi Indonesia, Tbk., dalam periode penelitian 7 tahun yaitu dari tahun 2006-2012.

\subsection{Saran}

Berdasarkan hasil penelitian yang telah dikemukakan, maka penulis mengajukan saran sebagai berikut:

1. Perusahaan diharapkan mampu mengefisienkan biaya dengan baik agar alokasi biaya dapat tepat dalam mendukung peningkatan nilai penjualan perusahaan, terutama dalam biaya-biaya yang memiliki kontribusi besar dalam mencapai tujuan perusahaan.

2. Penelitian selanjutnya diharapkan dapat mengembangkan penelitian ini dengan lebih baik. Penelitian selanjutkan dapat menambahkan dan menganalisis faktor lain yang dapat mempengaruhi pencapaian nilai penjualan suatu perusahaan, misalnya pemberian kompensasi atau pengendalian biaya produksi.

\section{Daftar Pustaka}

Arikunto, Suharsimi. 2002. Prosedur Penelitian, Suatu Pendekatan Praktek. Jakarta: PT Rineka Cipta.

Bustami, Bastian \& Nurlela. 2007. Akuntansi Biaya. Yogyakarta: Graha Ilmu

Cron \& Decarlo. 2010. Sales Management, Edisi 9. John Wiley \& Sons Pte Ltd.

Dani, Irene Kusuma. 2007. Hubungan Periklanan, Publisitas dan Promosi Penjualan terhadap Penjualan. Malang.

Dunia, Firdaus Ahmad \& Abdullah, Wasilah. 2009. Akuntansi Biaya. Jakarta: Penerbit Salemba Empat.

FASB. 2003. Statement of Financial Accounting Concepts No. 6 : Elements of Financial Statements.

Fisher, R.A. \& Yates, F. Statistical Tables for Biological Agricultural and Medical Research. Oliver and Boyd. Ltd. Edinburgh.

Fortuinisa, Ananda \& Agassi, Andrew Arief. 2013. Pesan Iklan Televisi dan Personal Selling: Alat Promosi Untuk Peningkatan Keputusan Pembelian. Jakarta: Journal Communication Spectrum.

Ghozali, Imam. 2009. Aplikasi Analisis Multivariate Dengan Program SPSS, Edisi Keempat. Penerbit Universitas Diponegoro.

Harahap \& Safri, Sofyan. 2003. Teori Akuntansi, Edisi Kelima. Jakarta: PT. Raspindo.

Hongren, Charles T., Srikant M., Datar \& George, Foster. 2005. Akuntansi Biaya Penekanan Manajerial. Diterjemahkan oleh Adhariani, Desi. Jakarta: PT Indeks kelompok Gramedia.

Horngren, Charles T. \& Harrison, Walter T. 2007. Akuntansi Jilid Satu, Edisi Tujuh. Jakarta: Penerbit Erlangga. 
Kotler, Philip \& Armstrong, Gary. 2010. Principles of Marketing, 13th Edition. New Jersey: Prentice-Hall, Inc.

Kotler, Philip. 2005. Manajamen Pemasaran, Jilid 1 dan 2. Jakarta: PT. Indeks Kelompok Gramedia.

Mulyadi. 2005. Akuntansi Biaya, Edisi 5. Yogyakarta: Aditya Media.

Saladin, Djaslim. 2003. Manajemen Pemasaran, Bandung: PT. Linda Karya.

Sanusi, Anwar. 2003. Metodologi Penelitian Praktis Untuk Ilmu Sosial dan Ekonomi, Edisi Pertama, Cetakan Pertama. Malang: Penerbit Buntara Media.

Setiaji, B. 2004. Panduan Riset dengan Pendekatan Kuantitatif, Surakarta: PPS Universitas Muhammadiyah.

Shimp, Terence A., 2007. Integrated Marketing Communication In Advertising and Promotion, Edisi Ketujuh. New York: McGrawHill.

Stanton, William J. 2003. Prinsip Pemasaran, Jilid 1, Edisi kesepuluh, cetakan kesepuluh. Diterjemahkan oleh Y. Lamarto. Jakarta: Erlangga.

Sugiyono. 2007. Metode Penelitian Administrasi. Bandung: CV Alfabeta.

Swastha, Basu. 2004. Pengantar Bisnis Modern. Jakarta: Salemba Empat.

Swastha, Basu. 2005. Manajemen Penjualan, Cetakan Keduabelas. Yogyakarta: Penerbit Liberty.

Tjiptono, Fandy. 2008. Manajemen Jasa. Yogyakarta: Penerbit Andi.

Winarto, Sigit \& Ismaya, Sujana. 2003. Kamus Besar Ekonomi by Indonesia, Edisi Pertama. Bandung: Pustaka Grafika.

Winarto, Sigit dan Ismaya, Sijana. 2003. Kamus Besar Ekonomi. Bandung: Penerbit Pustaka Grafika.

Witjaksono, Armanto. 2006. Akuntansi Biaya. Yogyakarta: Graha Ilmu.

www.idx.co.id

www.telkom.co.id 